No $74-M A Y 1967$

\title{
THE
}

\section{INTERNATIONAL REVIEW OF THE}

\section{RED CROSS}

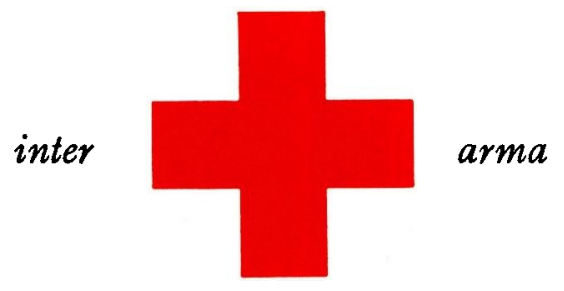

caritas

INTERNATIONAL COMMITTEE OF THE RED CROSS GENEVA 


\section{INTERNATIONAL REVIEW \\ OF THE RED CROSS}

SEVENTH YEAR - No. 74

MAY 1967

CONTENTS

J. MEINICH: The latest social task of the Norwegian Red Cross: Prison Visitors

Page 235

INTERNATIONAL COMMITTEE OF THE RED CROSS Twenty-first award of the Florence Nightingale Medal (Circular No. 467)

EXTERNAL ACTIVITIES

Vietnam - ICRC President in Asia

\section{IN GENEVA}

ICRC Training Courses . . . . . . . . . . . . . . . . . . . 248

An ICRC publication . . . . . . . . . . . . . . . . . . . . . . . . 249

In the Yemen: ICRC medical teams at work . . . . . . . . 250

\section{IN THE RED CROSS WORLD}

Germany (Federal Republic). . . . . . . . . . . . . . . 253

In Vietnam. . . . . . . . . . . . . . . . . . . . . . 257

Red Crescent help to pilgrims . . . . . . . . . . . . 261

\section{MISCELIANEOUS}

The medical projession's responsibilities today (J.-G. L.) . . . 263 In memory of an ICRC delegate . . . . . . . . . . . . . 271

Service for refugees . . . . . . . . . . . . . . . . . . 272

Flying doctors . . . . . . . . . . . . . . . . . . . . . 273

BOOKS AND REVIEWS 


\title{
FRENCH EDITION OF THE REVIEW
}

The French edition of this Review is issued every month under the title of Revue internationale de la Croix-Rouge. It is, in principle, identical with the English edition and may be obtained under the same conditions.

\section{SUPPLEMENTS TO THE REVIEW}

\author{
SPANISH
}

R. H. Gluns: El Servicio de Transfusión de Sangre de la Cruz Roja Canadiense. - 200 Día Mundial de la Cruz Roja.

\section{GERMAN}

R. H. Gluns: Der Bluttransfusionsdienst des Kanadischen Roten Kreuzes. - 20. Welttag des Roten Kreuzes.

\section{THE}

INTERNATIONAL REVIEW OF THE RED CROSS

is published each month by the International Committee of the Red Cross

7, avenue de la Paix, 1211 Geneva. I, Switzerland Postal Cheque No. 12.1767

Annual subscription: Sw. fr. $25 .-(\$ 6)$

Single copies Sw. fr. $2.50(\$ 0.60)$

Editor : J.*G. LossIER

The International Committee of the Red Cross only assumes responsibility for material over its own signature. 